De Jure: Jurnal Hukum dan Syari'ah

Vol. 9, No. 2, 2017, h. 73-87

ISSN (Print): 2085-1618, ISSN (Online): 2528-1658

DOI: http://dx.doi.org/10.18860/j-fsh.v9i2.

Available online at http://ejournal.uin-malang.ac.id/index.php/syariah

\title{
Perlindungan Hak Anak Dalam Perkawinan Poligami Di Indonesia
}

\author{
Nurul Aini \\ Pengadilan Agama Kuningan, Indonesia \\ nurulaini@gmail.com
}

\begin{abstract}
Abstrak:
The problem of polygamy is actually not only related to the relationship between husband and wife, but also concerns how children can still develop their potential. Some children's problems do not entirely become the responsibility of the family, but also the government. The purpose of this study is to describe the protection of children in polygamous marriage according to Muhammad Syahrur viewed from the perspective of Law No. 23 of 2002 concerning Child Protection. This research belongs to normative juridical research using statute approach and conceptual approach. The results showed based on the hudûd theory of Muhammad Syahrur that Shahrur's thoughts on polygamy were in line with what the Indonesian government was trying to maintain and protect children's rights even though in the different forms. In addition, according to the researcher, it needs to be added regarding the cumulative requirements contained in Law No. 1 Number 1974 concerning Marriage as contained in Article 2 letter b and d of Law No. 23 of 2002 concerning Child Protection as a condition for a husband to apply for polygamy.
\end{abstract}

Problematika poligami sebenarnya bukan terkait hubungan antara suami dan istri saja, tetapi juga menyangkut bagaimana anak tetap bisa mengembangkan potensinya. Sebagian persoalan anak memang tidak sepenuhnya menjadi tanggung jawab keluarga, tetapi juga pemerintah. Tujuan penelitian ini adalah untuk mendeskripsikan perlindungan anak dalam perkawinan poligami menurut Muhammad Syahrur ditinjau dari perspektif UU No. 23 Tahun 2002 tentang Perlindungan Anak. Penelitian ini tergolong penelitian yuridis normatif dengan menggunakan statute approach dan conceptual approach. Hasil penelitian menunjukkan berdasarkan teori hudûd Muhammad Syahrur bahwa pemikiran Syahrur tentang poligami tersebut sejalan dengan apa yang diupayakan pemerintah Indonesia untuk memelihara dan melindungi hak-hak anak meskipun dari bentuk dan perwujudannya berbeda. Selain itu, menurut peneliti perlu ditambahkan terkait persyaratan kumulatif yang terdapat dalam UU No. 1 Tahun 1974 tentang Perkawinan sebagaimana yang terdapat dalam Pasal 2 huruf b dan d UU No. 23 Tahun 2002 tentang Perlindungan Anak sebagai syarat seorang suami akan mengajukan permohonan poligami.

Kata Kunci: poligami; perkawinan; hak anak. 


\section{Pendahuluan}

Permasalahan poligami menjadi topik yang penting terutama dalam kaitanya dengan state law dan adanya perbedaan interpretasi dalam memahami ayat al-Qur'an. Surat al-Nisâ (4) ayat 3 menjadi legitimasi ulama klasik mengenai kebolehan poligami ${ }^{1}$, sedangkan sebagian kalangan modernis menganggap bahwa kebolehan poligami dalam ayat tersebut berada dalam ruang yang sempit yang hanya dapat dilakukan dalam keadaan darurat bagi orang yang membutuhkannya dengan syarat yang ketat, bahkan diantara mereka juga ada yang tegas menolak poligami tersebut ${ }^{2}$. Dilain itu, meski alQur'an sebagai sumber ajaran menjelaskan tentang poligami bukan berarti Islam-lah yang membawa ajaran poligami sehingga tuduhan bahwa Islam adalah pembawa ajaran poligami juga tidaklah tepat, ${ }^{3}$ mengingat poligami sudah ada jauh sebelum Islam seperti halnya pada zaman kuno di Yunani, China, India, Babilonia, Asyria, Mesir, dan lainlainnya ${ }^{4}$. Ajaran Islam datang justru memberikan batasan terhadap tindakan poligami dengan syarat yang tidak mudah dan bahkan ketentuan ayat al-Qur'an tentang poligami merupakan pesan moral dari al-Qur'an untuk memelihara dan menyantuni anak yatim. Pasalnya, ayat tersebut turun lantaran kondisi perang yang menyebabkan banyaknya janda dan anak yatim ${ }^{5}$.

Menarik untuk dikaji bagaimana pandangan Muhammad Syahrur sebagai salah satu tokoh modernis Islam tentang poligami dikaitkan tentang perlindungan anak ditinjau dari perspektif hukum Indonesia yang merujuk pada UU No. 23 Tahun 2002 tentang Perlindungan Anak. Toni Pransiska dalam kajiannya menuliskan bahwa Syahrur melakukan kolaborasi antara penerapan teori hudûd dengan pemahaman linguistik untuk memberikan pendangan baru tentang poligami. Tinjauan unsur teks yang dikaitkan dengan realita sosial, membuat Syahrur berpandangan bahwa poligami merupakan solusi atas permasalahan masyarakat dengan ketentuan syarat yang harus terpenuhi. ${ }^{6}$

Penelitian Khozainul Ulum menyebutkan bahwa menurut Syahrur terdapat unsur kemanusiaan dan sosial dalam poligami. Lebih lanjut menurutnya, Allah tidak hanya membolehkan poligami, tetapi lebih dari itu menganjurkan poligami dengan syarat adanya kekhawatiran terhadap pemeliharaan anak yatim. Dengan kata lain, menurut Syahrur, istri yang akan dipoligami haruslah seorang janda yang memiliki anak yatim. Ketentuan syarat ini menjadi pembeda pemikiran antara Syahrur dengan ulama klasik pro poligami. Dilain itu, konsep Syahrur dinilai jauh berbeda dengan intelektual Muslim modern yang cenderung untuk melarang poligami dengan alasan utama yakni kemustahilan bagi seorang poligan untuk berbuat adil terhdap para istrinya ${ }^{7}$.

\footnotetext{
${ }^{1}$ Abd Moqsith, "Tafsir Atas Poligami Dalam Al-Qur'an," KARSA: Journal of Social and Islamic Culture 23, no. 1 (June 5, 2015): 136, https://doi.org/10.19105/karsa.v23i1.613.

${ }^{2}$ Moqsith, 140-46.

${ }^{3}$ Siti Musdah Mulia, Islam Menggugat Poligami (Jakarta: PT Gramedia Pustaka Utama, 2007), 44.

4 Makrum Makrum, "Poligami Dalam Perspektif Al-Qur'an," MAGHZA: Jurnal Ilmu Al-Qur'an dan Tafsir 1, no. 2 (November 14, 2016): 38, https://doi.org/10.24090/maghza.v1i2.739.

5 Zunly Nadia, "Membaca Ayat Poligami Bersama Fazlur Rahman,” Mukaddimah: Jurnal Studi Islam 2, no. 1 (2017): 217.

${ }^{6}$ Toni Pransiska, "Rekonstruksi Konsep Poligami Ala Muhammad Syahrur: Sebuah Tafsir Kontemporer," Hikmah Journal of Islamic Studies 12, no. 2 (2016): 187-206.

7 Khozainul Ulum, "Poligami Dalam Pandangan Muhammad Syahrur: Pembacaan Ulang Terhadap Makna Dan Ketentuan Poligami," Al Hikmah: Jurnal Studi Keislaman 5, no. 1 (March 18, 2015): 1-13, http://ejournal.kopertais4.or.id/pantura/index.php/alhikmah/article/view/515.
} 
Sejalan dengan pandangan Syahrur, Pemerintah Indonesia juga melakukan upayaupaya dalam memelihara dan melindungi hak-hak anak. Salah satu upaya tersebut adalah dengan dikeluarkannya Undang-Undang No 23 Tahun 2002 tentang perlindungan anak yang menyatakan bahwa bahwa anak merupakan makhluk yang harus dilindungi dari berbagai bahaya yang akan menimpanya, anak harus tumbuh dan berkembang baik fisik maupun mental. ${ }^{8}$ Undang-undang ini disahkan oleh pemerintah sebagai perwujudan untuk melaksanakan pemenuhan, pemajuan, perlindungan hak anak bagi seluruh anak Indonesia yang berlaku bagi semua jenis kelamin, ras, agama dan etnis. Persoalan perlindungan anak khususnya anak yatim seringkali dianggap kurang penting dalam kajian poligami. Poligami selalu diukur dari kemampuan pelaku dalam hal moril yaitu kasih sayang dan atau materiil saja. Padahal jika melihat realita sosial, banyak dijumpai para poligan mempunyai istri kedua, ketiga dan atau keempatnya terdiri dari perempuan yang masih perawan dan lebih muda bahkan lebih cantik dari istri pertama, tanpa lebih jauh memandang kepentingan dan kesejahteraan anak yatim. Lebih lanjut, poligami dikatakan sebagai penindasan terhadap perempuan, pelanggaran terhadap Hak Asasi Manusia yang tidak mengaitkan eksistensi anak yatim dalam konteks itu. Atas dasar itu, seorang poligan dihadapkan pada persoalan apakah dia mampu memelihara dan melindungi anak-anaknya sehingga permasalahanpermasalahan anak yang dewasa ini mengkhawatirkan menjadi sedikit terselesaikan. ${ }^{9}$

\section{Metode Penelitian}

Penelitian ini merupakan penelitian yuridis normatif atau penelitian hukum kepustakaan. Pendekatan yang digunakan dalam penelitian ini adalah pendekatan perundang-undangan (statute approach) dan pendekatan konseptual (conceptual approach). Penelitian ini menelaah sebuah undang-undang perlindungan anak yang berkaitan dengan isu hukum yang diteliti dan menelaah konsep yang beranjak dari pandangan-pandangan dan doktrin yang berkembang dalam ilmu hukum yaitu tentang perlindungan anak dalam perkawinan poligami menurut Muhammad Syahrur. Data Primer diambil dari UU No. 23 Tahun 2002 tentang Perlindungan Anak; UU No. 35 Tahun 2014 tentang Perubahan Atas UU No. 23 Tahun 2002 tentang Perlindungan Anak; dan buku-buku referensi Muhammad Syahrur. Sedangkan data sekunder berasal dari artikel jurnal, biro statistik, buku-buku dan literature lain terkait dengan penelitian. Selanjutnya data yang diperoleh dianalisa dengan pendekatan content analysis.

\section{Hasil dan Pembahasan}

\section{Perkawinan Poligami Dalam Pandangan Muhammad Syahrur}

Poligami berasal dari bahasa Yunani, yaitu apolus yang mempunyai arti banyak, serta gamos yang mempunyai arti perkawinan. Maka ketika kata ini digabungkan akan berarti suatu perkawinan yang banyak dan bisa jadi dalam jumlah yang tidak terbatas. ${ }^{10}$ Adapun secara terminologis, poligami dapat dipahami sebagai suatu keadaan di mana seorang suami memiliki istri lebih dari satu orang. Seorang suami yang berpoligami dapat saja beristri dua orang, tiga orang, empat orang, atau bahkan lebih dalam waktu

\footnotetext{
8 Jamilia Susanti, "Tinjauan Hukum Islam Terhadap Undang-Undang No. 23 tahun 2002 Tentang Perlindungan Anak," Medina-Te : Jurnal Studi Islam 12, no. 2 (2016): 110.

${ }^{9}$ Rodli Makmun, Poligami Dalam Tafsir Muhammad Syahrur : Rodli Makmun (STAIN Ponorogo, 2009), 5-6.

${ }^{10}$ Labib MZ, Pembelaan Ummat Manusia (Surabaya: Bintang Pelajar, 1986), 15.
} 
bersamaan. ${ }^{11}$ Poligami dapat dibedakan menjadi dua macam, yaitu poliandri dan poligini. Poliandri adalah perkawinan seorang perempuan dengan lebih dari seorang laki-laki. Sedangkan poligini adalah perkawinan seorang laki-laki dengan lebih dari seorang perempuan. ${ }^{12}$

Pandangan Syahrur tentang poligami diawali dengan cara penafsirannya terhadapap al-Qur'an surat an-Nisâ' (4) ayat 3. Menurutnya, dalam surat al-Nisa' (4) tersebut diawali dengan seruan kepada manusia agar bertakwa kepada Allah serta seruan untuk menyambung tali silaturrahim. Kemudian di ayat kedua, Allah memerintahkan kepada manusia agar memberikan harta benda anak yatim dan tidak memakannya. Selanjutnya, Allah kembali membahas tentang anakanak yatim dengan menikahi perempuan yang disenangi: dua, tiga atau empat yang dapat dilakukan hanya pada kondisi takut tidak dapat berbuat adil kepada anakanak yatim. Kemudian ayat keempat Allah melanjutkan pembahasan tentang mas kawin dan mahar bagi perempuan, dan pada ayat kelima tentang larangan kepada manusia untuk menyerahkan kepada orang-orang yang belum sempurna akalnya harta benda mereka, kemudian (pada ayat keenam) Allah membicarakan tentang anak-anak yatim lagi. ${ }^{13}$

Syahrur dalam menafsirkan ayat tentang poligami tidak memisahkan ayat sebelumnya begitu juga ayat sesudahnya yang membicarakan tentang anak yatim. Atas dasar itu, Syahrur mengatakan bahwa pembicaraan tentang poligami berkaitan dengan anak yatim. Menurut Syahrur, kata yatim dalam bahasa Arab berarti seorang anak yang belum mencapai umur baligh yang telah kehilangan ayahnya, sementara ibunya masih hidup. Sedangkan yatim yang berarti seorang anak yang telah kehilangan ayahnya ${ }^{14}$, sebagaimana disebutkan dalam firman Allah QS. al-Kahfi [18]: 82 : "adapun dinding rumah itu adalah milik dua anak yatim di kota itu, yang di bawahnya ada harta bagi mereka berdua, dan ayahnya seorang yang saleh". Dalam menerjemahkan ayat "dan jika kamu takut tidak akan dapat berlaku adil terhadap anak-anak yatim”, Syahrur menunjukkan pembolehan atas poligami dengan menikahi ibu- ibunya yang menjanda. Kemudian ayat selanjutnya: “...maka kawinilah perempuan-perempuan yang kamu senangi..." adalah penunjukan kepada orang-orang yang telah menikah dengan seorang wanita dan memiliki anak. Karena bukan dinamakan poligami bagi lelaki bujangan yang mengawini janda yang mempunyai anak-anak yatim. Sebab pada kalimat selanjutnya disebutkan “...dua, tiga, atau empat..". ${ }^{15}$

Syahrur menafsirkan ayat "... mâ thâba lakum” (perempuan-perempuan yang kamu senangi), menurut Syahrur adalah sebagai bentuk pemuliaan, penghormatan dan menjaga perasaannya dari Allah kepada para janda yang memiliki anak-anak yatim yang telah kehilangan pemimpin dan penopang hidup keluarganya. Allah menggunakan kata-kata dengan sangat halus dan penuh perasaan. Padahal bagi Allah boleh-boleh saja berfirman: fankihû mâ shi'tum min an-nisâ'i (maka kawinilah wanita-wanita yang kamu kehendaki). Akan tetapi Allah berfirman: fankihû mâ thâba lakum min an-nisâ'i (maka kawinilahperempuan-perempuan yang kamu senangi). Selanjutnya dalam kata "fa in khiftum an lâ ta'dilû', menurut Muhammad Syahrur berkaitan dengan pemahaman

\footnotetext{
${ }^{11}$ Nashruddin Baidan, Upaya Penggalian Konsep Perempuan Dalam Al-Qur'an (Mencermati Konsep Kesejajaran Perempuan Dalam Al-Qur'an) (Yogyakarta: Pustaka Pelajar, 1999), 94.

${ }^{12}$ Makrum, "Poligami Dalam Perspektif Al-Qur'an," 37-38.

${ }^{13}$ Muhammad Syahrur, Metodologi fiqih Islam kontemporer, trans. Sahiron Syamsuddin (Yokyakarta: ELSAQ Press, 2004), 425.

${ }^{14}$ Syahrur, 427.

${ }^{15}$ Makmun, Poligami Dalam Tafsir Muhammad Syahrur, 85.
} 
sosial kemasyarakatan, bukan konsep biologis, dan berkisar pada masalah anakanak yatim dan berbuat baik kepadanya serta berlaku adil terhadapnya. ${ }^{16}$

Lebih lanjut, Syahrur berpandangan bahwa ayat poligami berisi batas minimal dan batas maksimal yang hadir secara bersamaan. Menurutnya QS. an-Nisâ' ayat 3 merupakan ayat hudûdiyyah yang menggabungkan batas maksimal dan batas minimal dalam sebuah kuantitas dan kualitas sekaligus ${ }^{17}$. Ayat-ayat hudûd dalam masalah poligami adalah sebagai berikut:

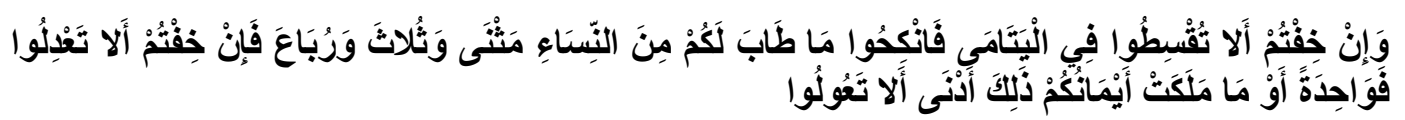

Artinya: "Dan jika kamu takut tidak akan berlaku adil terhadap (hak-hak) perempuan yatim (bilamana kamu mengawininya), maka kawinilah wanitawanita (lain) yang kamu senangi; dua, tiga atau empat. Kemudian jika kamu takut tidak akan berlaku adil, maka (kawinilah) seorang saja, atau budakbudak yang kamu miliki. Yang demikian itu adalah lebih dekat kepada tidak berbuat aniaya" (QS. an-Nisâ' [4]: 3).

Menurut Syahrur terdapat dua kata kunci pada ayat tersebut. Dua kata yang dimaksud yaitu qasatha dan 'adala. Dalam bahasa Arab kedua lafal tersebut masingmasing memiliki dua potensi makna yang paradoksal. Qasatha mempunyai dua potensi makna: Pertama, al-'adlu ma'a almusâ'adah (berlaku adil dengan memberikan pertolongan), seperti yang terdapat dalam QS. al-Maidah [5]: 42, QS. al-Hujurât [49]: 9, dan QS. al-Mumtahanah [60]: 8, dan kedua, azh-zhulmu wa al-jûr (berbuat aniaya dan berbuat tidak adil), seperti tertera dalam QS. al-Jinn [72]: 14. Sementara itu, dua potensi makna yang terdapat dalam kata 'adala ialah: (1) berbuat lurus (istiwâ'), dan (2) berbuat tidak lurus atau menyimpang (i’wijâj). Dari dua makna bagi kedua lafal tersebut, makna yang dimaksud pada QS. an-Nisâ [4]: 3 ialah potensi makna yang pertama, yakni berbuat baik dan adil.Meskipun demikian, Syahrur tidak memandang bahwa kata qasatha merupakan sinonim dari kata 'adala. Keduanya meskipun memiliki persinggungan makna, tetapi mempunyai perbedaan konotasi. Maksudnya bahwa makna keadilan dalam kata qasatha dipandang dari satu arah atau tanpa adanya perbandingan. Sementara itu, "berbuat adil" yang dimaksud oleh kata 'adala ialah "bersikap adil antara dua pihak yang berbeda" (musâwah baina tharafain mukhtalifain). ${ }^{18}$

Ayat tentang poligami ini memiliki hubungan erat dengan ayat sebelumnya karena ada redaksi wa-in yang menghubungkan keduanya, sementara ayat sebelumnya membicarakan hak-hak anak yatim. Allah berfirman: "Dan berikanlah kepada anakanak yatim (yang sudah baligh) harta mereka, jangan kamu menukar yang baik dengan yang buruk dan jangan kamu makan harta mereka bersama hartamu. Sesungguhnya tindakan-tindakan (menukar dan memakan) itu adalah dosa yang besar" (QS. an-Nisâ' [4]: 2). Ayat-ayat poligami yang termasuk ayat-ayat hudûdiyah ini memberikan batasan maksimal dan minimal, baik dari sisi jumlah/kuantitas maupun kualitas. ${ }^{19}$

Syahrur mengemukakan bahwa ayat hudud tersebut membicarakan pernikahan dengan redaksi "fankihu" yang kemudian mengawali jumlah istri dengan angka dua

\footnotetext{
${ }^{16}$ Syahrur, Metodologi fiqih Islam kontemporer, 428-29.

17 Muhyar Fanani and Fuad Mustafid, Fiqh madani: konstruksi hukum Islam di dunia modern (Yogyakarta: LKiS, 2010), 284.

18 Nurjannah Ismail, Perempuan dalam pasungan: bias laki-laki dalam penafsiran (Yogyakarta: LKiS Yogyakarta, 2003), 227-28.

${ }^{19}$ Syahrur, Metodologi fiqih Islam kontemporer, 235.
} 
(matsna). Seorang laki-laki dapat dikatakan menikahi dirinya sendiri atau menikahi setengah orang perempuan, maka batas minimal istri adalah satu orang perempuan, dan batas maksimalnya adalah empat orang perempuan. Proses peningkatan jumlah ini diawali dari dua, tiga, dan terakhir empat dalam hitungan bulat karena manusia tidak dapat dihitung dengan angka pecahan. Kesimpulannya, batas minimal jumlah perempuan yang dinikahi adalah satu dan batas maksimalnya adalah empat. Penyebutan satu-persatu jumlah perempuan dalam redaksi matsna wa tsulatsa wa rubâ' harus dipahami sebagai penyebutan bilangan bulat secara berurutan, sehingga tidak dapat dipahami sebagai 'dua + tiga + empat' yang berjumlah sembilan. ${ }^{20}$

Menurut Syahrur, yang dimaksud dengan kualitas adalah apakah istri kedua dan seterusnya adalah perempuan yang janda atau perawan. Jika janda, apakah janda yang punya anak atau tanpa anak. sehingga kita dapat memperoleh pemahaman sebagai berikut: ayat ini tidak menyebutkan syarat kualitas bagi istri pertama, sehingga terbuka kemungkinan apakah ia seorang perempuan, janda dengan anak atau janda tanpa anak. Agar terjadi keserasian antara redaksi jawaban syarat "fankihû..." dan redaksi syaratnya, yaitu keadilan kepada para anak yatim, ayat ini harus dipahami sebagai ayat yang sedang membicarakan para ibu janda dari anakanak yatim. Sehingga dapat disimpulkan bahwa ayat ini memberikan kelonggaran dari segi jumlah hingga empat istri, tetapi menetapkan persyaratan bagi istri kedua, ketiga dan keempat harus seorang perempuan yang berstatus janda yang memiliki anak. Konsekuensinya, seorang laki-laki yang menikahi janda ini harus memelihara anak yatim yang ikut bersamanya sebagaimana ia memelihara dan mendidik anak-anaknya sendiri.

Jika seseorang mampu menikahi tiga janda yang masing-masing memiliki anak, sehingga ia harus bertanggung jawab atas kesejahteraan hidup mereka selain istri pertama dan anak-anaknya sendiri, atau dengan kata lain ia hidup dengan sebuah keluarga besar yang tentunya dari sisi finansial kondisi ini merupakan tanggung jawab yang sangat besar sehingga ada kekhawatiran terjadi ketidakseimbangan dan ketidakadilan dalam keluarga tersebut. Dalam kondisi inilah kita dapat lebih memahami firman Allah "fa-in khiftum allâ ta'dilu fa-wâhidatan" yang berarti berlaku adil pada anak-anak yatim yang ikut bersama istri-istrinya yang lain. Dalam ayat ini pengertian 'adl (bertindak adil antara dua pihak) tampak dengan jelas, yaitu tindakan adil seorang bapak kepada anak-anak dari istri pertama dan kepada anak-anak dari istri-istri lainnya. ${ }^{21}$

Sedangkan tindakan qist hanya ditujukan kepada anak-anak yatim saja, yaitu anak-anak yang dibawa oleh istri kedua, ketiga dan keempat, sebagaimana firman Allah yang artinya:"Jika seorang laki-laki yang sudah beristri khawatir tidak dapat berbuat adil, baik terhadap anak-anaknya sendiri maupun anak-anak yatim tersebut, maka hendaklah ia menikah dengan satu perempuan saja “. Maka dapat disimpulkan bahwa hudûd minimal poligami adalah satu istri tanpa memperdulikan apakah ia perawan atau janda, sedangkan hudûd maksimalnya adalah empat istri dengan catatan istri kedua hingga keempat adalah janda cerai mati atau hilang suaminya yang masih memiliki tanggungan anak-anak. Selanjutnya menurut Syahrur, ayat 3 surat an-Nisâ' ini tidak bisa dilepaskan dari ayat 2 dan 6-nya yang berbicara mengenai pemeliharaan anak-anak yatim. Oleh karena itu, poligami juga harus dipahami dalam kerangka pemeliharaan anak yatim. Atas dasar itu, harus diingat bahwa selamanya tidak diperbolehkan seorang

\footnotetext{
${ }^{20}$ Syahrur, 235.

${ }^{21}$ Syahrur, 237-38.
} 
suami menikahi janda yang punya anak, namun ia hanya menerima janda tersebut dan menelantarkan anak-anak dari janda tersebut. ${ }^{22}$

Dalam buku Nahw Ushûl Jadîdah li al-Fiqh al-Islami fiqh al-Mar'ah, Muhammad Syahrur mengatakan bahwa:

\begin{abstract}
"Perintah poligami akan menjadi solusi bagi berbagai problem yang amat besar, yang menurut perjuangan kemasyarakatan (untuk menanganinya), antara lain: 1) adanya seorang laki-laki di sisi seorang janda akan mampu menjaga dan memeliharanya dari keterperosokan dalam perbuatan keji; 2) penyediaan tempat perlindungan yang aman bagi anak-anak yatim di mana mereka dapat berkembang, dan 3) menjamin keberadaan sang ibu di sisi anak-anaknya untuk mendidik dan menjaga mereka..."23
\end{abstract}

Syahrur menegaskan bahwa poligami baru boleh dilakukan dengan syarat: 1) istri kedua, ketiga, dan keempat adalah para janda yang memiliki anak yatim; 2) harus terdapat rasa khawatir tidak dapat berbuat adil kepada anak-anak yatim. Bila kedua syarat itu tidak terpenuhi maka perintah poligami menjadi gugur ${ }^{24}$.

\title{
Perlindungan Anak dalam Perkawinan Poligami dalam Pandangan Muhammad Syahrur dan Undang-Undang
}

Melalui teori hudûd, Muhammad Syahrur mengelompokkan masalah poligami dalam kategori posisi batas maksimal dan minimal bersamaan dalam sebuah kuantitas dan kualitas sekaligus. Dari segi kuantitas, batas minimal poligami adalah satu perempuan, sedangkan batas maksimalnya adalah empat perempuan. Sementara dari segi kualitas, istri kedua sampai keempat harus janda yang cerai mati, bukan cerai talak yang masih memiliki tanggungan anak yatim. Dengan demikian, hudud minimal poligami adalah satu istri tanpa memperdulikan ia perawan atau janda. Sedangkan hudud maksimalnya adalah empat istri dengan catatan istri kedua hingga keempat adalah janda cerai mati/hilang suaminya yang masih memiliki tanggungan anak-anak. Dari sini dapat disimpulkan bahwa persyaratan poligami menurut Syahrur ada dua; (1) istri kedua, ketiga dan keempat adalah janda yang mempunyai anak yatim, (2) bisa berbuat adil.

Dari beberapa persyaratan yang telah diungkapkan Syahrur tersebut, bisa diketahui bahwa seseorang yang akan melakukan poligami harus memilah dahulu jandajanda mana yang memiliki anak yatim. Tidak boleh seseorang yang akan melakukan poligami hanya melihat bagaimana kondisi janda yang akan dinikahi saja. Karena sesungguhnya konteks poligami menurut Syahrur bukan terletak pada bagaimana seseorang itu menikahi banyak wanita khususnya janda, melainkan bagaimana kondisi para anak yatim yang ditinggal mati ayahnya dari janda-janda yang akan dinikahinya. Di sini kita melihat perbedaan konsep poligami antara Ulama dan Muhammad Syahrur. Karena pada intinya, Syahrur ingin menunjukkan keperdulian sosial terhadap anak dan para wanita. Sehingga tidak heran jika dia mengaitkan permasalahan poligami dengan perlindungan anak. Persyaratan poligami yang diungkapkan Syahrur tersebut memang berat, karena tidak semua laki-laki mempunyai kemampuan secara moril maupun materiil untuk memelihara, melindungi, dan menafkahi banyak istri dan anak-anaknya.

\footnotetext{
22 Syahrur, 239.

${ }^{23}$ Muhammad Syahrur, Nahw Ushûl Jadîdah Li Al-Fiqh Al-Islami Fiqh Al-Mar'ah (Damaskus: alAhâlî lî ath-Thibâ'ah wa an-Nasyr wa at-Tawzî', 2000), 304.

${ }^{24}$ Fanani and Mustafid, Fiqh madani, 287.
} 
Selain itu, persyaratan adil yang dikatakan Syahrur tidak hanya adil dalam hal materi saja, melainkan juga adil dalam hal pemberian kasih sayang terhadap anak-anaknya. Karena adil yang dimaksud Syahrur bukan terletak kepada para istrinya yang dalam hal ini adalah pemenuhan kebutuhan biologis, melainkan adil terhadap anak-anaknya dalam pemenuhan hak-haknya.

Pelaksanaan perlindungan anak di Indonesia mengacu pada ketentuan Pasal 2 Undang-undang No. 23 Tahun 2002 jo. Undang-Undang No. 35 Tahun 2014 tentang Perlindungan Anak yang menyebutkan bahwa:

"Penyelenggaraan perlindungan anak berasaskan Pancasila dan berlandaskan Undang-Undang Dasar Negara Republik Indonesia Tahun 1945 serta prinsip-prinsip dasar Konvensi Hak-Hak Anak meliputi: a.non diskriminasi; b. kepentingan yang terbaik bagi anak; c. hak untuk hidup, kelangsungan hidup, dan perkembangan; dan $d$. penghargaan terhadap pendapat anak." 25

Undang-undang ini menegaskan bahwa pertanggung jawaban orang tua, keluarga, masyarakat, pemerintah dan negara merupakan rangkaian kegiatan yang dilaksanakan secara terus-menerus demi terlindunginya hak-hak anak. Rangkaian kegiatan tersebut harus berkelanjutan dan terarah guna menjamin pertumbuhan dan perkembangan anak, baik fisik, mental, spiritual maupun sosial. Pemerintah Daerah juga berkewajiban dan bertanggung jawab melaksanakan dan mendukung kebijakan nasional dalam penyelenggaraan perlindungan anak di daerah. Pemerintah Daerah dalam melaksanakan kewajiban dan tanggung jawab melalui upaya daerah membangun kabupaten/kota layak anak. Hal ini tertuang dalam Pasal 21:

"Negara, Pemerintah, dan Pemerintah Daerah berkewajiban dan bertanggung jawab menghormati pemenuhan Hak Anak tanpa membedakan suku, agama, ras, golongan, jenis kelamin, etnik, budaya dan bahasa, status hukum, urutan kelahiran, dan kondisi fisik dan/atau mental" 26

Perlindungan anak di sini sesuai dengan prinsip-prinsip pokok yang terkandung dalam Konvensi Hak-hak Anak. Yang dimaksud dengan asas kepentingan yang terbaik bagi anak sebagaimana yang terdapat di dalam Pasal 2 yang menyatakan bahwa bahwa dalam semua tindakan yang menyangkut anak yang dilakukan oleh pemerintah, masyarakat, badan legislatif, dan badan yudikatif, maka kepentingan yang terbaik bagi anak harus menjadi pertimbangan utama. Sedangkan yang dimaksud dengan asas hak untuk hidup, kelangsungan hidup, dan perkembangan adalah hak asasi yang paling mendasar bagi anak yang dilindungi oleh negara, pemerintah, masyarakat, keluarga, dan orang tua. Selanjutnya yang dimaksud dengan asas penghargaan terhadap pendapat anak adalah penghormatan atas hak-hak anak untuk berpartisipasi dan menyatakan pendapatnya dalam pengambilan keputusan terutama jika menyangkut hal-hal yang mempengaruhi kehidupannya ${ }^{27}$. Apabila pemikiran Syahrur dikaitkan dengan Bab II Pasal 2 UU No. 23 Tahun 2002 tentang Perlindungan Anak, seorang suami yang hendak

\footnotetext{
25 Undang-Undang Nomor 23 Tahun 2002 jo. Undang-Undang Nomor 35 Tahun 2014 tentang Perlindungan Anak

26 Undang-Undang Nomor 23 Tahun 2002 jo. Undang-Undang Nomor 35 Tahun 2014 tentang Perlindungan Anak.

27 Undang-Undang Nomor 23 Tahun 2002 jo. Undang-Undang Nomor 35 Tahun 2014 tentang Perlindungan Anak
} 
berpoligami maka dia akan mempertimbangkan bagaimana nantinya memberikan perlindungan, bersikap adil, dan memenuhi kebutuhan bagi anak-anak yatim yang dibawa oleh para janda yang akan dinikahinya dengan: tanpa adanya diskriminasi; memperhatikan kepentingan yang terbaik bagi anak-anaknya; memperhatikan perkembangannya; menjamin hidup anak-anaknya; dan menghargai apapun pendapat yang disampaikan oleh anaknya. Apabila dia tidak memenuhi persyaratan itu, maka dikatakan oleh Syahrur, hak untuk berpoligaminya menjadi gugur. Tindakan ini dimaksudkan semata-mata untuk mewujudkan kehidupan terbaik bagi anak yang diharapkan sebagai penerus bangsa yang potensial, tangguh, memiliki nasionalisme yang dijiwai oleh akhlak mulia dan nilai Pancasila, serta berkemauan keras menjaga kesatuan dan persatuan bangsa dan negara.

Di Indonesia, hukum perkawinan nasional menganut asas monogami. Sebagaimana yang diatur di dalam Pasal 3 ayat (1) UU No. 1 Tahun 1974 tentang Perkawinan: "Pada azasnya dalam suatu perkawinan seorang pria hanya boleh mempunyai seorang istri. Seorang wanita hanya boleh mempunyai seorang suami". ${ }^{28}$ Ketentuan ini ditransfer dari garis hukum yang terdapat di dalam QS. an-Nisâ' [4]: 3 yang meletakkan dasar monogami bagi sebuah perkawinan. Tetapi undang-undang tersebut memberi kemungkinan bagi seorang suami untuk melakukan poligami. Dan bagi seorang suami yang ingin berpoligami diharuskan memninta izin kepada pengadilan dengan alasan-alasan sebagaimana yang terdapat di dalam Pasal 4 ayat (2) UU No. 1 Tahun 1974 tentang Perkawinan, yaitu: " $a$. istri tidak dapat menjalankan kewajibannya sebagai istri; $b$. istri mendapat cacat badan atau penyakit yang tidak dapat disembuhkan; c. istri tidak dapat melahirkan keturunan”. Alasan-alasan sebagaimana yang terdapat dalam pasal tersebut bersifat fakultatif, artinya salah satu saja dari tiga hal itu dijadikan alasan permohonan poligami ke pengadilan dan pemohon dapat mendukung alasan permohonannya dengan bukti-bukti yang cukup, maka permohonannya untuk beristri lebih dari satu orang dapat dikabulkan oleh pengadilan ${ }^{29}$.

Kemudian persyaratan lain yang harus dipenuhi oleh seorang suami yang akan mengajukan permohonan izin berpoligami kepada pengadilan, sebagaimana diatur dalam Pasal 5 (1) UU No. 1 Tahun 1974 tentang Perkawinan yaitu: "a. harus ada persetujuan dari istri; $b$. harus ada kepastian bahwa suami mampu menjamin keperluan-keperluan hidup istri-istri dan anak-anak mereka; c. harus ada jaminan bahwa suami akan berlaku adil terhadap istri-istri dan anak-anak mereka”. Persyaratan yang tercantum dalam Pasal 5 ayat (1) tersebut bersifat kumulatif, artinya pengadilan hanya dapat memberi izin poligami kepada suami apabila semua persyaratan tersebut telah terpenuhi. Jika satu syarat saja tidak terpenuhi, maka Pengadilan Agama harus menolak permohonan tersebut ${ }^{30}$.

Praktik poligami di Indonesia telah marak terjadi baik yang dilakukan secara terang-terangan dan dilegalkan di KUA atau catatan sipil maupun yang dilakukan secara sembunyi-sembunyi (di bawah tangan). Pelakunya pun juga memiliki latar belakang beragam baik tingkat pendidikan, tingkat ekonomi serta profesi dengan maksud dan motivasi yang bervariasi. Tetapi harus kita perhatikan dalam syarat kumulatif yang telah disebutkan dalam Pasal 5 ayat (1) di atas, bahwa dalam perkawinan poligami tidak hanya seorang suami istri saja yang terlibat, tetapi anak-anak juga menjadi bagian dari

\footnotetext{
${ }^{28}$ Undang-Undang Nomor 1 Tahun 1974 tentang Perkawinan

${ }^{29}$ M. Anshary MK, Hukum Perkawinan Di Indonesia : Masalah-Masalah Krusial (Pustaka Pelajar, 2010), 90.

${ }^{30}$ Anshary MK, 90.
} 
keluarga itu. Dari berbagai riset yang telah dilakukan mengenai efek poligami bagi anak di antaranya: 1. Hasil penelitian menunjukkan bahwa anak-anak dari keluarga poligami lebih banyak mengalami dampak dari akibat konflik perkawinan dibanding yang monogami, seperti kekerasan dalam keluarga dan kenakalan anak; 2. Perselisihan memiliki efek langsung pada status kesehatan mental anak-anak. Dalam sebuah studi pada anak usia 8 sampai 18, perilaku anak yang tidak dapat dikendalikan $11 \%$-nya dipengaruhi oleh konflik perkawinan dan tidak efektifnya peran orang tua akibat poligami; 3. Gangguan perkembangan anak-anak yang diakibatkan oleh perkawinan poligami adalah sebagai berikut: miskin kompetensi sosial, stress, miskin prestasi sekolah, serta kenakalan dan brutalitas; 4. Konflik perkawinan poligami juga cenderung mengganggu efektivitas orang tua dalam keterlibatan mendidik anak. Anak-anak yang mengalami konflik perkawinan yang intens cenderung menggunakan perilaku agresif yang berlebihan sebagai sarana pemecahan masalah, menunjukkan pola bermusuhan dalam berinteraksi dengan teman, dan dapat dipaksa untuk melawan orang tua yang lain (yang bukan ibu kandungnya). ${ }^{31}$

Dari berbagai efek negatif yang ditimbulkan oleh adanya orang tua yang berpoligami, maka sebelum melakukan poligami harus dipertimbangkan apakah dengan adanya poligami membawa pengaruh yang baik bagi anak. Dijelaskan juga di dalam Pasal 2 huruf b UU No. 23 Tahun 2002 tentang Perlindungan Anak bahwa keluarga bertanggung jawab atas perlindungan anak dengan memperhatikan kepentingan yang terbaik bagi anak yaitu bahwa dalam semua tindakan yang menyangkut anak yang dilakukan oleh pemerintah, masyarakat, badan legislatif, dan badan yudikatif, maka kepentingan yang terbaik bagi anak harus menjadi pertimbangan utama. Kemudian dijelaskan juga dalam Pasal 2 huruf d bahwa di dalam perlindungan anak menganut asas penghargaan terhadap pendapat anak yaitu penghormatan atas hak-hak anak untuk berpartisipasi dan menyatakan pendapatnya dalam pengambilan keputusan terutama jika menyangkut hal-hal yang mempengaruhi kehidupannya yang dalam hal ini adalah orang tua yang akan melakukan poligami. Sehingga dalam hal ini peneliti berpendapat bahwa seharusnya persyaratan kumulatif yang terdapat dalam Pasal 5 UU No. 1 Nomor 1974 tentang Perkawinan tersebut harus ditambahkan poin-poin sebagaimana yang terdapat dalam Pasal 2 huruf b dan d UU No. 23 Tahun 2002 tentang Perlindungan Anak sebagai syarat seorang suami akan mengajukan permohonan poligami.

Perlindungan anak sebagaimana yang telah disyaratkan oleh Syahrur dalam perkawinan poligami, di dalam hukum keluarga Islam disebut sebagai hadhanah atau pemeliharaan dan pengasuhan anak. Para ahli fiqh mendefinisikan hadhanah ialah: "melakukan pemeliharaan anak- anak baik laki-laki ataupun perempuan yang masih kecil ataupun yang sudah besar tetapi belum tamyiz tanpa perintah dari padanya, menyediakan sesuatu yang menjadikan kebaikannya, menjaganya dari sesuatu yang menyakiti dan merusaknya, mendidik jasmani dan rohani dan akalnya agar mampu berdiri sendiri menghadapi hidup dan memikul tanggung jawabnya”. Mengasuh anak yang masih kecil hukumnya wajib. Sebab mengabaikannya berarti mengahadapkan anak-anak yang masih kecil kepada bahaya kebinasaan. ${ }^{32}$

Hukum hadhanah ini hanya dilaksanakan ketika pasangan suami istri bercerai dan memiliki anak yang belum cukup umur. Selain itu hadhanah juga berlaku bagi anak

\footnotetext{
${ }^{31}$ Kompasiana, "Faktor dan Efek Poligami bagi Anak", http://sosbud.kompasiana.com/2011/06/26/faktor-dan-efek-poligami-bagi-anak/, diakses tanggal 12 Mei 2016.

32 Sayyid Sabiq, Fiqhus Sunnah, trans. Moh Thalib (Bandung: al Ma'arif, 1990), 160.
} 
yang telah ditinggal mati oleh orang tuanya. Hal ini disebabkan karena anak masih perlu penjagaan, pengasuhan, pendidikan, perawatan dan melakukan berbagai hal demi kemaslahatannya atau yang biasa disebut dengan perwalian. Dalam hal hadhanah ini, seorang anak yang telah ditinggal mati oleh ayahnya, maka seseorang yang berhak mendapatkan hak asuhnya tidak lain adalah ibunya. Jika dilihat dari perspektif UU No. 23 Tahun 2002 tentang Perlindungan Anak, menurut Pasal 7 ayat (2): "dalam hal karena suatu sebab orang tuanya tidak dapat menjamin tumbuh kembang anak, atau anak dalam keadaan terlantar maka anak tersebut berhak diasuh atau diangkat sebagai anak asuh atau anak angkat oleh orang lain sesuai dengan ketentuan peraturan perundang-undangan yang berlaku",33.

Dari undang-undang tersebut, dijelaskan apabila ketika seorang anak terlantar hidupnya, maka berhak untuk diasuh oleh orang lain. Tapi tidak dengan pendapat Muhammad Syahrur, bagi seorang anak terlantar yang dalam hal ini ditinggal mati oleh ayahnya, maka ibunya diperbolehkan untuk menikah lagi dengan laki-laki lain agar seorang anak tidak kehilangan sosok ayah dalam hidupnya serta untuk menjamin tumbuh kembang anak tersebut. Tetapi ketika kita melihat realita kebanyakan di masyarakat kita khususnya di Jawa, ketika seorang anak kehilangan atau ditinggal mati oleh ayahnya maka ibunya masih bisa melindungi bahkan bisa untuk menanggung semua kebutuhan dirinya dan anak-anaknya. Bahkan secara terang-terangan ada yang mengatakan bahwa perempuan bisa survive sendiri tanpa seorang laki-laki di sisinya. Dari pernyataan ini bisa kita simpulkan bahwa di masyarakat kita, anak-anak tidak akan terlantar hidupnya ketika dia tidak mempunyai seorang ayah di sisinya. Tetapi secara psikis, tumbuh kembang anak akan berbeda ketika dia didampingi seorang ayah di sisinya dengan seorang anak yang tidak mempunyai ayah yang ikut mendampingi dalam tumbuh kembangnya.

Baik perlindungan, pengasuhan maupun pemeliharaan anak dalam pembahasan manapun hukumnya selalu wajib dan harus dilakukan. Ini dikarenakan anak yang masih memerlukan hal tersebut akan mendapatkan bahaya jika tidak mendapatkan perlindungan, pengasuhan, maupun pemeliharaan. Selain itu ia juga harus tetap diberi nafkah dan diselamatkan dari segala hal yang dapat merusaknya. Namun, ketika terjadi kasus seorang anak ditinggal mati oleh ayahnya kemudian yang ada hanya ibunya yang secara moril maupun materiil tidak mampu untuk merawatnya seorang diri, maka tidak ada pilihan lain bagi dirinya untuk menikah lagi untuk mendapatkan pelindung dan pemenuh kebutuhan bagi dirinya dan anaknya. Perlindungan anak-anak yatim dalam perkawinan poligami menurut Syahrur memang tidak dijelaskan bagaimana kriterianya. Hanya saja dikatakan, poligami boleh dilakukan dengan pertimbangan adanya rasa adil dalam hal pembagian kasih sayang, pemenuhan kebutuhan dan lain sebagainya dengan tidak mengabaikan hak-hak anak yatim yang dibawa oleh janda-janda yang dinikahinya. Dalam perspektif Islam, hak-hak anak yang wajib diperhatikan menurut Syahrur telah banyak disinggung di dalam al-Qur'an maupun hadits Nabi. Selanjutnya dijelaskan dalam Pasal 13 ayat (1) dan (2) UU No. 23 Tahun 2002 tentang Perlindungan Anak bahwa:

"Setiap anak selama dalam pengasuhan orang tua, wali, atau pihak lain mana pun yang bertanggung jawab atas pengasuhan, berhak mendapat perlindungan dari perlakuan: a. diskriminasi; b. eksploitasi, baik ekonomi maupun seksual; c. penelantaran; d. kekejaman, kekerasan, dan penganiayaan;

33 “Undang - Undang (UU) RI No.23 Tahun 2002 Tentang Perlindungan Anak” Pasal 7 ayat (2). 
e. ketidakadilan; dan f. perlakuan salah lainnya. (2) Dalam hal orang tua, wali atau pengasuh anak melakukan segala bentuk perlakuan sebagaimana dimaksud dalam ayat (1), maka pelaku dikenakan pemberatan hukuman."34

Pasal ini menjelaskan bahwa seorang anak yang berada di bawah pengasuhan orang tuanya atau walinya berhak mendapat perlindungan dari perlakuan diskriminasi, misalnya perlakuan yang membeda-bedakan suku, agama, ras, golongan, jenis kelamin, etnik, budaya dan bahasa, status hukum anak, urutan kelahiran anak, dan kondisi fisik dan/atau mental. Selain itu, harus dilindungi dari perlakuan eksploitasi, misalnya tindakan atau perbuatan memperalat, memanfaatkan, atau memeras anak untuk memperoleh keuntungan pribadi, keluarga, atau golongan. Tidak hanya itu saja, seorang anak harus dilindungi dari perlakuan penelantaran, misalnya tindakan atau perbuatan mengabaikan dengan sengaja kewajiban untuk memelihara, merawat, atau mengurus anak sebagaimana mestinya. Selain itu, harus dihindarkan dari perlakuan yang kejam, misalnya tindakan atau perbuatan secara zalim, keji, bengis, atau tidak menaruh belas kasihan kepada anak. Perlakuan kekerasan dan penganiayaan juga harus dihindari, misalnya perbuatan melukai dan/atau mencederai anak, dan tidak semata-mata fisik, tetapi juga mental dan sosial. Selain itu, seorang anak juga dilindungi dari perlakuan ketidakadilan, misalnya tindakan keberpihakan antara anak yang satu dan lainnya, atau kesewenang-wenangan terhadap anak; dan yang terakhir adalah perlakuan salah lainnya, misalnya tindakan pelecehan atau perbuatan tidak senonoh kepada anak ${ }^{35}$.

Maraknya kekerasan seksual terhadap anak yang semakin meningkat secara signifikan akan mengancam dan membahayakan jiwa anak, merusak kehidupan pribadi dan tumbuh kembang anak, serta mengganggu rasa kenyamanan, ketentraman, keamanan, dan ketertiban masyarakat. Sebagaimana yang terdapat di dalam UU No. 23 Tahun 2002 dan UU No. 35 Tahun 2014 tentang Perlindungan Anak bahwa sanksi pidana yang dijatuhkan bagi pelaku kekerasan seksual terhadap anak belum memberikan efek jera dan belum mampu mencegah secara komprehensif terjadinya kekerasan seksual terhadap anak. Sehingga pemerintah berinisiatif untuk membuat peraturan baru mengenai Perlindungan Anak yang berfokus pada sanksi bagi pelaku kekerasan seksual terhadap anak yaitu Perpu No. 1 Tahun 2016 tentang Perubahan Kedua Atas UU No. 23 Tahun 2003 tentang Perlindungan Anak. Dalam salah satu pasal Peraturan Pemerintah Pengganti Undang-undang tersebut disebutkan bahwa dalam hal tindak pidana dilakukan oleh orang tua, wali, orang-orang yang mempunyai hubungan keluarga, pengasuh anak, pendidik, tenaga kependidikan, aparat yang menangani perlindungan anak, atau dilakukan oleh lebih dari satu orang secara bersama-sama, pidananya ditambah $1 / 3$ (sepertiga) dari ancaman pidana yaitu penjara paling singkat 5 (lima) tahun dan paling lama 15 (lima belas) tahun dan denda paling banyak Rp5.000.000.000,00 (lima miliar rupiah). ${ }^{36}$ Dari semua penjelasan pasal di atas, kita bisa mengetahui bahwa seseorang yang bertanggung jawab atas pemeliharaan anak harus memperhatikan poin-poin yang terdapat di dalam pasal tersebut. Tidak boleh seseorang lalai dan memperlakukan anak semaunya tanpa memperhatikan pasal tersebut

\footnotetext{
34 “Undang - Undang (UU) RI No.23 Tahun 2002 Tentang Perlindungan Anak" Pasal 13 ayat (1) dan (2).

${ }^{35}$ Lembaran Negara RI Tahun 2002 No. 109, Penjelasan atas "Undang - Undang (UU) RI No.23 Tahun 2002 Tentang Perlindungan Anak.”

36 "Lembaran Negara RI Tahun 2016 No. 99, Perpu No. 1 Tahun 2016 Tentang Perubahan Kedua Atas UU No. 23 Tahun 2003 Tentang Perlindungan Anak," n.d., http://ditjenpp.kemenkumham.go.id/arsip/ln/2016/uu17-2016bt.pdf.
} 
sehingga menyebabkan kerugian fisik maupun psikis terhadap anak. Jika melanggar salah satu poin saja, maka akan dikenai sanksi terhadapnya sesuai hukum yang berlaku.

Jika dikaitkan dengan pemikiran Syahrur, seorang suami yang poligami dengan alasan perlindungan anak maka dia juga dituntut untuk memperlakukan anak sebagaimana yang terdapat di dalam Pasal 13 ayat (1) dan (2) UU No. 23 Tahun 2002 tentang Perlindungan Anak tersebut. Apabila dia tidak mampu untuk itu, maka kiranya dia mempertimbangkan untuk tetap melakukan poligami atau mencukupkan dengan satu istri dan anak-anak dari seorang istri tersebut. Tetapi jika seorang suami yang akan berpoligami benar-benar mampu untuk melindungi, memelihara dan memperlakukan anak sebaik mungkin sesuai dengan isi dari Pasal 13 ayat (1) dan (2) UU No. 23 Tahun 2002 tentang Perlindungan Anak tersebut, maka dia akan diamanati tanggung jawab besar sebagaimana yang terdapat di dalam Pasal 26 ayat (1) UU No. 23 Tahun 2002 tentang Perlindungan Anak yaitu: "a) mengasuh, memelihara, mendidik, dan melindungi anak; b) menumbuhkembangkan anak sesuai dengan kemampuan, bakat, dan minatnya; dan c) mencegah terjadinya perkawinan pada usia anakanak". ${ }^{37}$ Ketentuan pasal 26 ayat (1) dalam UU No. 23 Tahun 2002 ini ditambah 1 (satu) huruf, yakni huruf d dalam UU No. 35 Tahun 2014 tentang Perubahan Atas UU No. 23 Tahun 2002 yang berbunyi: "memberikan pendidikan karakter dan penanaman nilai budi pekerti pada Anak". ${ }^{38}$

Syahrur melihat ada beberapa lembaga penampungan anak-anak yatim yang memang telah memenuhi sebagian tempat tinggal bagi mereka, menurutnya tidak dapat menjamin kehidupan seorang anak. Sebab hal itu malah dapat menjauhkan dan memisahkan mereka dengan ibu kandung mereka. Meskipun demikian, hal ini tidak menghilangkan akan pentingnya lembaga dan yayasan-yayasan dalam masyarakat yang menampung anak-anak yatim yang telah kehilangan orang tuanya. ${ }^{39}$ Sehingga solusi yang terbaik adalah menghadirkan orang tua yang lengkap dalam kehidupan anak demi tumbuh kembangnya sebagaimana yang dikatakan Syahrur sebagai persyaratan dalam melakukan poligami. Dari beberapa penjelasan yang sudah dipaparkan, bahwa pemikiran Muhammad Syahrur tentang poligami ini bagi peneliti sendiri merupakan salah satu solusi yang baik dalam rangka untuk melindungi anak-anak yang nota-bene nya terlantar dalam keluarganya yaitu dalam hal meninggalnya ayah mereka. Sebagaimana yang sudah dijelaskan bahwa yang dimaksud poligami di dalam penelitian ini adalah "pernikahan seorang laki-laki yang telah menikah dengan janda yang memiliki anak; karena bukan termasuk poligami bagi lelaki bujangan yang mengawini janda yang tidak memiliki anak-anak yatim”. Begitu juga dengan perintah poligami, ketika terjadi kasus anak yang telah kehilangan kedua orang tuanya maka gugurlah masalah poligami. Demikian juga halnya dengan kematian seorang ibu, sementara suaminya masih hidup sehingga apabila suami menikah lagi dengan perempuan lain, maka istri keduanya tersebut tidak termasuk dalam kategori poligami. Perhatian Syahrur terhadap perlindungan anak memang tergolong tinggi. Tidak heran jika dia mengaitkan permasalahan poligami dengan perlindungan anak. Sehingga dari upayanya tersebut penting bagi kita untuk berfikir bagaimana sesungguhnya kita menginterpretasikan ayat yang berkaitan dengan poligami.

\footnotetext{
37 Undang-Undang Nomor 23 Tahun 2002 jo. Undang-Undang Nomor 35 Tahun 2014 tentang Perlindungan Anak

38 Undang-Undang Nomor 23 Tahun 2002 jo. Undang-Undang Nomor 35 Tahun 2014 tentang Perlindungan Anak.

${ }^{39}$ Syahrur, Metodologi fiqih Islam kontemporer, 430.
} 


\section{Kesimpulan}

Melalui teori batas Muhammad Syahrur, dapat disimpulkan bahwa hudûd minimal poligami adalah satu istri tanpa memperdulikan apakah ia perawan atau janda, sedangkan hudûd maksimalnya adalah empat istri dengan catatan istri kedua hingga keempat adalah janda cerai mati/hilang suaminya yang masih memiliki tanggungan anak-anak. Kesimpulan ini dihasilkan Syahrur setelah ia menganalisis QS. an-Nisâ' [4]: 3 dengan menggunakan metode intra-tekstual dan sosiologis sekaligus. Menurutnya, ayat 3 surat an-Nisâ' ini tidak bisa dilepaskan dari ayat 2 dan 6-nya yang berbicara mengenai pemeliharaan anak-anak yatim. Oleh karena itu, poligami juga harus dipahami dalam kerangka pemeliharaan anak yatim. Pemikiran Syahrur dalam permasalahan perlindungan anak dalam perkawinan poligami, jika dilihat dari perspektif Undang-undang Perlindungan Anak sejalan dengan apa yang diupayakan pemerintah dalam melindungi hak-hak anak di Indonesia sebagaimana yang terdapat di dalam pasal-pasalnya meskipun dari segi bentuk dan perwujudannya berbeda. Meskipun Syahrur tidak menjelaskan aspek atau hak-hak anak apa saja yang perlu dilindungi. Namun keduanya, baik dari pemikiran Muhammad Syahrur dan Undang-undang Perlindungan Anak mempunyai tujuan yang sama yakni upaya pemeliharaan dan perlindungan anak. Dan perlu ditambahkan juga terkait persyaratan kumulatif yang terdapat dalam Pasal 5 UU No. 1 Nomor 1974 tentang Perkawinan, harus ditambahkan poin-poin sebagaimana yang terdapat dalam Pasal 2 huruf b dan d UU No. 23 Tahun 2002 tentang Perlindungan Anak sebagai syarat seorang suami akan mengajukan permohonan poligami.

\section{Daftar Pustaka}

Anshary MK, M. Hukum Perkawinan Di Indonesia: Masalah-Masalah Krusial. Pustaka Pelajar, 2010.

Baidan, Nashruddin. Upaya Penggalian Konsep Perempuan Dalam Al-Qur'an (Mencermati Konsep Kesejajaran Perempuan Dalam Al-Qur'an). Yogyakarta: Pustaka Pelajar, 1999.

Fanani, Muhyar, and Fuad Mustafid. Fiqh madani: konstruksi hukum Islam di dunia modern. Yogyakarta: LKiS, 2010.

Ismail, Nurjannah. Perempuan dalam pasungan: bias laki-laki dalam penafsiran. Yogyakarta: LKiS Yogyakarta, 2003.

Labib MZ. Pembelaan Ummat Manusia. Surabaya: Bintang Pelajar, 1986.

Makmun, Rodli. Poligami Dalam Tafsir Muhammad Syahrur : Rodli Makmun. STAIN Ponorogo, 2009.

Makrum, Makrum. "Poligami Dalam Perspektif Al-Qur'an." MAGHZA: Jurnal Ilmu AlQur'an dan Tafsir 1, no. 2 (November 14, 2016): 35-50. https://doi.org/10.24090/maghza.v1i2.739.

Moqsith, Abd. "Tafsir Atas Poligami Dalam Al-Qur'an.” KARSA: Journal of Social and Islamic Culture 23, no. 1 (June 5, 2015): 132-48. https://doi.org/10.19105/karsa.v23i1.613.

Musdah Mulia, Siti. Islam Menggugat Poligami. Jakarta: PT Gramedia Pustaka Utama, 2007.

Nadia, Zunly. "Membaca Ayat Poligami Bersama Fazlur Rahman." Mukaddimah: Jurnal Studi Islam 2, no. 1 (2017): 203-28. 
Pransiska, Toni. "Rekonstruksi Konsep Poligami Ala Muhammad Syahrur: Sebuah Tafsir Kontemporer." Hikmah Journal of Islamic Studies 12, no. 2 (2016): 187206.

Sayyid Sabiq. Fiqhus Sunnah. Translated by Moh Thalib. Bandung: al Ma'arif, 1990.

Susanti, Jamilia. "Tinjauan Hukum Islam Terhadap Undang-Undang No. 23 tahun 2002 Tentang Perlindungan Anak." Medina-Te : Jurnal Studi Islam 12, no. 2 (2016): 109-24.

Syahrur, Muhammad. Metodologi fiqih Islam kontemporer. Translated by Sahiron Syamsuddin. Yokyakarta: ELSAQ Press, 2004.

—. Nahw Ushîl Jadîdah Li Al-Fiqh Al-Islami Fiqh Al-Mar'ah. Damaskus: alAhâlî lî ath-Thibâ'ah wa an-Nasyr wa at-Tawzî', 2000.

Ulum, Khozainul. "POLIGAMI DALAM PANDANGAN MUHAMMAD SYAHRUR: Pembacaan Ulang Terhadap Makna Dan Ketentuan Poligami." Al Hikmah: Jurnal Studi Keislaman 5, no. 1 (March 18, 2015). http://ejournal.kopertais4.or.id/pantura/index.php/alhikmah/article/view/515.

Undang-Undang Nomor 23 Tahun 2002 tentang Perlindungan Anak

Undang-Undang Nomor 35 Tahun 2014 tentang Perubahan Atas Undang-Undang Nomor 23 Tahun 2002 tentang Perlindungan Anak

Undang-undang Nomor 1 Tahun 1974 tentang Perkawinan 